УДК 76:7.012(092)(477)

Євген ГУЛА,

професор кафедри рисунка та живопису Київського національного університету технологій та дизайну

Олександра КОЛІСНИК, доктор філософських наук, професор, професор кафедри рисунка та живопису Київського наиіонального університету технологій та дизайну

Оксана МАЗНІЧЕНКО, дочент кафедри рисунка та живопису Київського наиіонального університету технологій та дизайну

Тетяна КУГАЙ, доцент кафедри рисунка та живопису Київського наиіонального університету технологій та дизайну (Київ, Україна) evgenush.gula@gmail.com

\title{
Г. НАРБУТ ЯК АПОЛОГЕТ СУЧАСНОГО УКРАЇНСЬКОГО ГРАФІЧНОГО ДИЗАЙНУ
}

У изій статті здійснюється вивчення ролі Г. Нарбута як апологета сучасного українського графічного дизайну. Проаналізовані ключові поняття дослідження - графіка, плакат, графічний дизайн. Досліджене формування й реалізація творчості Г. Нарбута у мейнстрімі культурно-иіннісної епохи кіния XIX-початку XX століть, яка має узагальнюючу назву модерн. Розглянуті фактори, які спричинили визначальний вплив на творчість Г. Нарбута. Окреслені найбільші досягнення мития на ниві української графіки й мистецтва плаката. Виявлені особливі риси ролі Г. Нарбута для сучасного графічного дизайну Украӥни.

Ключові слова: графіка, плакат, плакатна графіка, дизайн, графічний дизайн, модерн, Г. Нарбут, етнічність, народна культура, традиція.

Yevhen HULA,

Professor of Drawing and Painting Department Kyiv National University of Technologies and Design

Oleksandra KOLISNYK,

Doctor of Philosophical Science, Professor, Professor of Drawing and Painting Department Kyiv National University of Technologies and Design

Oksana MAZINCHENKO, Assistant Professor of Drawing and Painting Department Kyiv National University of Technologies and Design

Tatyana KUHAY, Associate Professor of Drawing and Painting Department Kyiv National University of Technologies and Design (Kyiv, Ukraine),evgenush.gula@gmail.com

\section{H. NARBUT AS AN APOLOGIST FOR MODERN UKRAINIAN GRAPHIC DESIGN}

In this article studying of a role of $G$. Narbut as apologist of modern Ukrainian graphic design is carried out. Key concepts of a research - graphics, the poster, graphic design are analyzed. Formation and realization of creativity of G. Narbut in a mainstream of a cultural and valuable era of the end of XIX - the beginnings of the XX centuries which has the generalizing name a modernist style is investigated. Factors, which were the reason, defining influence 
on G. Narbut's creativity are considered. The biggest achievements of the artist on a field of the Ukrainian graphics and art are allocated to the poster. Special lines of a role of $G$. Narbut for modern graphic design of Ukraine are revealed.

In carrying out a research, the integrated approach caused by need of involvement of a comparative-historical method, which fixes similarity between the cultural phenomena as certificates of community of their origin was used. Application of culturological methodology, which includes sociocultural approach-important for this research as focuses attention on unity of culture and sociality, taking into account scientific achievements of cultural science, ethnography, psychology, history, etc. became necessary.

G. Narbut's creativity is a striking example of a modernist style in art of graphics and poster. The most famous G. Narbut's work as representative of the Ukrainian graphics is "The Ukrainian alphabet" where the master connected extreme simplicity and refinement of composition, having provided at the same time harmony of a picture and color. "The Ukrainian alphabet" of G. Narbut can still be considered as an unsurpassed model of font art thanks to what the artist deeply understood the principle of that cultural sphere, which we call graphic design now.

G. Narbut's achievements in the sphere of art of the poster are very successful. It is possible to claim that the 1920th years were marked by the new course of development of the Ukrainian graphics - "Narbut's school". G. Narbut considered domestic national style through a prism of new development of culturological heritage and tried to connect capacious contents to qualities of the versatile person. Visual language of "narbutovets" became a certain combination of national motives with achievements of futurism, expressionism and cubism. In the whole, G. Narbut put the idea of the embodiment of national images in graphic design.

From creative heritage of $G$. Narbut the modern graphic design could adopt harmony of combination natural and traditional with art and technological. Experience of the outstanding Ukrainian artist of the beginning of last century demonstrates that the design has to not only create subject and spatial forms, but also with their help to influence the attitude of people towards them. The addressing works by G. Narbut teaches contemporaries of expediency of use in graphic design of folk art as the primary source of development as basic values of national and applied creativity become a basis of strategic evolutionary programs of design.

Key words: graphics, poster, poster graphics, design, graphic design, modernist style, G. Narbut, ethnicity, national culture, tradition.

Постановка проблеми. Комплексна оцінка культурних та суспільних цінностей, які лягли в основу формування сучасного українського графічного дизайну, дає можливість нового погляду на численні мистецькі події, спонукає до нових дослідницьких результатів у сфері мистецької культури України. Серед вагомих питань у дослідженні образотворчого мистецтва та культури України кінця XIX - початку XX ст. є трактування творчого доробку Григорія Івановича Нарбута (1886-1920). Зокрема, дослідження творчості цього видатного художника-графіка й ілюстратора $€$ нині важливим аспектом вивчення мистецьких процесів країни загалом.

3 огляду на вказане, детальне й грунтовне вивчення значення постаті Г. Нарбута для формування творчого ідейно-ціннісного підгрунтя для графічного дизайну України модерної доби є нині актуальним. При цьому важливо, що розвиток культурної ідентичності вітчизняного дизайну означає, з одного боку, проникнення проектної свідомості в традиційну етнокультуру, з іншого, його відкритість до сприйняття цінностей інших цивілізаційних надбань.

Крім того, варто відзначити, що сучасні представники графічного дизайну України шукають в арсеналі історії мистецтва ті аутентичні риси, що сьогодні набувають особливої актуальності. Найбільший інтерес фахівців викликають ті сфери творчості минулого, що спрямовані на створення ідеальних естетично-практичних властивостей об'єктів матеріального середовища. Відшліфовані упродовж минулого століття об'єкти українського мистецтва успішно сполучають у собі естетичні, функціональні, ергономічні та технологічні властивості, а тому можуть стати зразком для графічних дизайнерів сучасності.

Взасмопов'язаність цієї дослідницької проблеми із важливими питаннями інших наук. Як відомо, починаючи з початку ХХ ст. дизайн розвиває міждисциплінарні і практичні зв'язки i3 психологією, народно-прикладним мистецтвом, культурологією, архітектурою, соціологією та ін. науками. У контексті вивчення творчості Г. Нарбута вартим уваги було б виявлення взаємопов’язаності графічного дизайну.

Аналіз останніх досліджень і публікацій, в яких започатковано розв'язання цієї проблеми. Творчості Г. Нарбута присвячене відносно незначне число спеціалізованих праць, причому знана частина 3 них являє собою каталоги виставок його робіт (Каталог виставки, 2006), матеріали відповідних мистецтвознавчих конференцій (Народний митець, 1986; Ювілей НАОМА, 2017) тощо. Значний масив відомостей про доробок Г. Нарбута можна знайти в узагальнюючих працях 3 історії українського образотворчого мистецтва й графіки на рубежі XIX - XX століть, а також присвячених загальним закономірностям формування епохи модерну в зазначений історичний період (Андрейканіч, 2013; Даниленко, 2005: 7-10). 
Що стосується питань дослідження графічного дизайну загалом та еволюції його окремих форм зокрема, то їм присвячені дослідження таких учених, як: О. Бойчук, О. Гладун, В. Грищенко, В. Даниленко, К. Кондратьєва, М. Король, О. Лагутенко, С. Прищенко, Н. Сбітнєва, О. Северіна, С. Смирнова, Л. Соколюк, П. Татіївський, Л. Триноженко, Л. Турчак, О. Черневич, Ю. Яворик та ін. Водночас є потреба в узагальненні значення саме творчого спадку Г. Нарбута для сучасного графічного дизайну в нашій країні.

Метою цієї статті $\epsilon$ оцінка ролі Г. Нарбута для формування сучасного українського графічного дизайну.

Об’єктом дослідження є творчий доробок Григорія Нарбута.

Методологія дослідження. У проведенні дослідження використовувався комплексний підхід, зумовлений необхідністю залучення порівняльно-історичного методу, що фіксує схожість між культурними явищами як свідчення спільності їх походження. Необхідним стало застосування культурологічної методології, що включає в себе соціокультурний підхід, важливий для нашого дослідження, оскільки акцентує увагу на єдності культури і соціальності з урахуванням наукових досягнень культурології, етнографії, психології, історії тощо.

Виклад основного матеріалу. Ключовими поняттями у контексті цього дослідження є графіка, плакат, дизайн і графічний дизайн. Графіка це реальна форма художньотворчої діяльності, що втілює художній зміст за допомогою лінії, плями та штриху (Король, 2012: 143). Графіка розподіляється на рисунок та друкарську графіку, що відрізняється здатністю швидко відгукуватися на актуальні події, зручністю тиражування в багатьох екземплярах та можливістю послідовного розкриття задуму в низці зображень.

У літературі присутній термін «плакатна графіка», що є художнім твором, виконаним в агітаційних, рекламних чи навчальних цілях. Плакатна графіка $є$ поліграфічним відтворенням створеного художником оригіналу. Відповідно, плакат - це вид друкованої графіки, що належить до іiї окремого різновиду - плакатної графіки, виконується за проектами митців у різних графічних та живописних техніках (Андрейканіч, 2013: 3).

Окремо слід виділити «дизайн» як вид пластичного мистецтва. У різний період часу це поняття набувало множинних трактувань, що віддзеркалювали його багатогранні аспекти. Проте нарізним стрижнем поняття дизайну, що не втратило своєї актуальності й сьогодні, стала категорія художньої проектності. Водночас, як вважає В. Даниленко, дизайн - це вид художньої діяльності, метою якої є проектування штучного середовища, що оточує людину та гармонує з природним (Даниленко, 2005: 9). Власне графічний дизайн дослідник визначає як художньо-проектну діяльність, основним засобом якої є графіка. Мета цієї діяльності - візуалізація інформації, призначена для масового поширення за допомогою поліграфії, кіно, телебачення, а також створення графічних елементів для промислових виробів і предметного середовища (Даниленко, 2005).

Метафора в графічному дизайні - це номінативний прийом i техніка сенсотворення, що здвоює уявлення про різні класи об'єктів в інформаційному контексті, з одного боку, і з міфологією архетипів образного мислення та емоційного сприйняття, 3 іншого (Макарова, 2012: 118). У візуально-пластичній мові, створюючи образ і апелюючи до уяви, метафора породжує зміст, сприйманий розумом.

Вперше в українському мистецтвознавстві подає історію вітчизняної графіки як художнього феномена, нового художнього стилю та напряму О. Лагутенко у своїх дослідженнях «Українська графіка першої третини XX сторіччя» та «Нариси з історії української графіки XX століття». Автор висловлює думку про те, що мистецтво українського плаката радянських часів має чітко визначені поняття та сформовані образи, актуальності набуває рекламний плакат, що акцентував увагу на соціальних та моральних сферах життя. Науковець підкреслює також комунікативну роль плаката в таких його проявах, як інформування, просвітництво та пропаганда. О. Лагутенко окреслює національні особливості та загальноєвропейські тенденції в розвитку вітчизняної графіки в XX ст.: «... митці прагнули бути в мистецтві національно свідомими, коли формувалися різні творчі угрупування, існували дві поділені кордоном частини України - «радянська» і «буржуазна», а чимало українських художників взагалі працювали у Парижі, Мюнхені, Берлині, Празі, Варшаві...» (Лагутенко, 2006: 3).

У роботі «Українська графіка першої третини XX століття: загальноєвропейські тенденції та національні особливості розвитку» (Лагутенко, 2006) О. Лагутенко пропонує нову концепцію історії української графіки першої третини XX століття у контексті загальноєвропейського художнього процесу. На думку дослідниці, «особливий інтерес до мистецтва графіки виник на початку XX століття під впливом нового світогляду, в якому вагому роль відігравали ідеї стилю 
модерн. Майстри, які сповідували в мистецтві ідеї цього стилю, ставилися до графіки як до художньої галузі, що має багаті можливості пластичної мови, здатна активізувати поступ до більшої умовності образних рішень, а також реалізувати жаданий синтез мистецтва й життя» (Лагутенко, 2006: 55). У розрізі загальної вітчизняної графіки науковець розглядає й плакатне мистецтво, що було її невіддільною частиною. Автор висловлює думку, що саме графіка першої третини XX ст. заклала конструктивні основи для «... формування нової концепції історії мистецтва...» та визначила шляхи, «...якими може рухатися сучасна культура України, зберігаючи національну ідентичність у світовому контексті, набуваючи потужного мистецького вияву» (Лагутенко, 2006: 60).

Переходячи власне до творчості Григорія Івановича Нарбута, відзначимо, що вона формувалася й реалізовувалася у мейнстрімі культурно-ціннісної епохи кінця XIX - початку XX століть, яка має узагальнюючу назву - модерн. Модерн («новий стиль»), виголосивши на межі XIX - XX ст. програму тотального оновлення та естетизації предметно-просторового середовища, залишився не тільки яскравим і самобутнім, неповторно своєрідним етапом у розвитку новітньої культури, але й передбачив подальшу долю мистецтва XX ст.

Роки панування модерну інколи називають «епохою 1900-го», і застосування такого багатозначного поняття, як «епоха», видається виправданим: незважаючи на свою недовготривалість, модерн зумів не просто втілитися в побуті, у мистецтві, у свідомості цілого покоління, а й надати ім особливого, лише йому властивого колориту. Саме тому «модерн» як науковий термін нерідко ставлять поряд не із суто стильовими категоріями, а $з$ таким історико-культурним поняттям, як «бідермаєр». В обох випадках ці терміни визначають собою не так стиль мистецтва, як стиль самого життя. Як наслідок, суспільно-естетичні та утилітарні функції мистецтва просякнуті світосприйняттям окремої людини і відображають iii життєві амбіції, спосіб існування в навколишньому світі (Івашко, 2009: 294).

Період модерну став періодом меценатства, бурхливого росту різноманітних художніх організацій, угрупувань, різнорідних творчих товариств. Вони визначали характер художнього життя, тут відбувалося не лише спілкування митців, але й діалоги зі споживачами, поціновувачами мистецтва, коло яких стрімко зростало. Поставав благотворний грунт для постійної міграції нових ідей із мистецтва елітарного в мистецтво масове. Проблема масової культури вперше зазвучала так гостро саме в межах модерну. Така парадоксальна діалектика елітарної та масової культур, їхні взаємоперехід та взаємоперетворення, взаємовпливи та самозаперечення кожної 3 них, починаючи від модерну, загалом характеризуватиме історію культури ХХ ст.

У період після 1917 року, попри складнощі і жахи воєнного часу, водночас актуальною стає проблема самоідентифікації та самовизначення художника як усередині країни, так і в контексті розвитку світового мистецтва. На території українських земель відбувається активний рух за національне відродження, переосмислення феномена української культури, кардинальний перегляд, а іноді й принципова зміна шкали мистецьких цінностей. Зміна усталеної уяви щодо національної культури докорінним чином трансформувала бачення стану і розвитку етнічної культури, зумовила її пріоритетне буття в суспільній свідомості. Незважаючи на мозаїчність художнього процесу, переважають авангардистські течії, змінюються функції мистецтва, його мова і стилістика.

Повною мірою зазначені тренди стосувалися i творчості Г. Нарбута, зокрема у сфері його графічного й плакатного мистецтва. Григорія Івановича за життя заслужено було поіменовано одним із найбільш видатних європейських графіків. Серед факторів, які спричинили визначальний вплив на його творчість, дослідники називають такі:

- давнє українське малярство і графіка XVII XVIII століть;

- геральдика українських родів, графіка українських рукописів і стародруків;

- широковідоме на рубежі XIX і XX століть об'єднання художників «Світ мистецтва» (Народний митець, 1986: 16).

Як відомо, найбільш відомим твором Г. Нарбута як представника української графіки $\epsilon$ «Українська абетка» (1917), де майстер поєднав граничну простоту і вишуканість композиції, забезпечивши при цьому гармонію малюнка й кольору. Зображаючи літери української абетки, Г. Нарбут активно запозичував як зразки української рукописної й друкованої книги, так і досягнення фахівців, які тоді розробляли шрифти в країнах Європи. До цих пір «Українська абетка» Г. Нарбута може вважатися неперевершеним зразком шрифтового мистецтва завдяки тому, що художник глибоко розумів засади тієї культурної сфери, яку ми нині називаємо графічним дизайном.

Варто також згадати про успіхи Г. Нарбута (у взаємодії з Антоном Середою) в оформленні української грошової одиниці (гривні) у період Української народної республіки (1917-1920рр.). 
Творчі зацікавлення Г. Нарбута образним світом фольклору та української старовини ставали засобом національного самоусвідомлення та самоствердження. Тенденція поєднання прикмет народного мистецтва 3 формальними рисами раннього модернізму позначилася на сюжетах його творів, де поширення набули сцени 3 традиційного селянського побуту, зображення свят, звичаїв, ремесел, народних виробів.

Переходячи до плакатного спадку Григорія Нарбута, слід наголосити на тому, що «нарбутівський» плакат став синтезом різних жанрів, форм, стилів і мистецьких напрямів. У період творчості Г. Нарбута український плакат постає як принципове інноваційне явище, оскільки увібрав у себе традиції українського мистецтва, національнокультурні звичаї, а тому можна говорити про його національну маркованість. Факторами, які вплинули на становлення «нарбутівського» плаката, стали війни та революції, рух відродження нації та економічний занепад, якими ознаменувався період першої третини XX століття (Лагутенко, 2006: 13).

На початку XX століття український плакат зазнав впливу польського та російського графічного мистецтва. Рубіж століть окремі дослідники, зокрема Н. Сбітнєва, визначають як переломний та масштабний, що завдяки технічним винаходам революційно вплинув на розвиток графічного дизайну. Зазначене стало поштовхом для комерціалізації плакатного мистецтва та привернення «... уваги до товару і його реалізації» (Сбітнєва, 2007: 155).

Поступово культурна взаємодія в царині графічного дизайну поширилася. У період з 1910 по 1930 рр. українські митці з графічного дизайну переймали дослід паризьких, віденських, московських та ін. колег. У цей час було створено Українську академію мистецтв, яка в подальшому відіграла значку роль у формуванні української школи дизайну та зокрема харківського плаката. 3 цією Академією пов'язані імена не лише Г. Нарбута, але й М. Бойчука та В. Кричевського (Лагутенко, 2006: 44).

Г. Нарбут заклав ідею втілення національних образів у графічному дизайні. Він пропонував використовувати в графіці елементи та культурні надбання минулих епох, так звані «цитати», «алюзії», «ремінісценції» та будь-які інші інтертекстуальні елементи, властиві модернізму. У Г. Нарбута символи та форми народного мистецтва стали використовувати в плакаті у вигляді геометричного орнаменту, який містив елементи рослинного чи тваринного світу. На початку XX сто- ліття геометричні елементи народно-прикладного мистецтва знайшли відображення у комерційних плакатах, які рекламували харчові та промислові вироби - цигарки, солодощі, напої. У цей період спостерігається прагнення митця до візуалізації народних образів, символічних та пластичних мотивів, наприклад традицій іконопису, народних ремесел та художнього промислу.

Насамкінець варто зауважити кілька принципових аспектів у контексті виявлення ролі Г. Нарбута для сучасного графічного дизайну України. Як відомо, графічний дизайн на території нашої країни виходить на новий щабель, стає простором, в якому кожен може реалізувати потребу в гармонійному середовищі. Він матеріалізує культурний вимір історії, пристосовуючи модерність до минулих традицій та народної культури. На нашу думку, від творчості Г. Нарбута сучасний дизайн міг би запозичити гармонію комбінування природно-традиційного із художньотехнологічним. Досвід видатного українського митця початку минулого століття свідчить про те, що дизайн має не лише створювати предметнопросторові форми, але і з їх допомогою впливати на ставлення до них людей.

Взявши за основу модель «традиція - інновація», яку активно використовував у своїх полотнах і плакатах Г. Нарбут, український графічний дизайн міг би реалізувати нові соціокультурні функції, пов'язані із спроможністю не лише створювати й концентрувати, але й експонувати та підсилювати накопичений «мистецький капітал».

Таким чином, проаналізувавши значення Г. Нарбута для формування засад сучасного українського графічного дизайну, ми дійшли таких висновків.

Творчість Г. Нарбута є яскравим прикладом модерну в мистецтві графіки й плаката. Серед факторів, які спричинили визначальний вплив на його творчість, дослідники називають: давнє українське малярство і графіку XVII - XVIII століть; геральдику українських родів, графіку українських рукописів і стародруків; широковідоме на рубежі XIX i XX століть об'єднання художників «Світ мистецтва». Найбільш відомим твором Г. Нарбута (як представника української графіки) є «Українська абетка», де майстер поєднав граничну простоту і вишуканість композиції, забезпечивши при цьому гармонію малюнка й кольору. Досі «Українська абетка» Г. Нарбута може вважатися неперевершеним зразком шрифтового мистецтва завдяки тому, що художник глибоко розумів засади тієї культурної сфери, яку ми нині називаємо графічним дизайном. 
Вельми успішними $є$ досягнення Г. Нарбута у сфері мистецтва плаката. Можна стверджувати про те, що 1920-і роки ознаменувались новою течією розвитку української графіки - «школа Нарбута». Сам Г. Нарбут розглядав вітчизняний національний стиль крізь призму нового розвитку культурологічної спадщини і намагався поєднати ємний зміст 3 якостями універсалу. Вплив Г. Нарбута помітний у пластичній мові плакатів А. Страхова й О. Маренкова. Візуальна мова «нарбутовців» стала певним поєднанням національних мотивів зі здобутками футуризму, експресіонізму та кубізму. Загалом Г. Нарбут заклав ідею втілення національних образів у графічному дизайні. Він пропонував використовувати в графіці елементи та культурні надбання минулих епох, так звані «цитати», «алюзії», «ремінісценції» та будь-які інші інтертекстуальні елементи, властиві модернізму.

Від творчого доробку Г. Нарбута сучасний графічний дизайн міг би перейняти гармонію комбінування природно-традиційного із художньо- технологічним. Досвід видатного українського митця початку минулого століття свідчить про те, що дизайн має не лише створювати предметнопросторові форми, але і з їх допомогою впливати на ставлення до них людей. Звернення до творів Г. Нарбута вчить сучасників доцільності використання у графічному дизайні народного мистецтва як першоджерела розвитку, оскільки базові цінності народно-прикладної творчості стають основою стратегічних еволюційних програм дизайну.

До перспектив подальших досліджень теми, яка розглянута у рамках цієї публікації, слід віднести: а) розгляд зарубіжних праць про історію української графіки початку XX століття, зокрема про твори Г. Нарбута; б) порівняльний аналіз графіки $Г$. Нарбута 3 іншими видатними ілюстраторами Російської імперії та Європи, пік творчості яких припадає на початок XX століття; в) оцінка запозичень творчого спадку Г. Нарбута у креативі сучасних митців графічного дизайну в Україні та за кордоном.

\section{СПИСОК ВИКОРИСТАНИХ ДЖЕРЕЛ}

1. Андрейканіч А. І. Плакат: його види та жанри. Українська культура: минуле, сучасне, шляхи розвитку. 2013. Вип. 19(1). С. 121-126.

2. Бурачек М. Спогади про Г. І. Нарбута. Бібліологічні вісті. 1927. № 1. С. 91-101.

3. Георгій Нарбут: посмертна вист. творів. Всеукр. іст. музей ім. Т. Шевченка. Київ: Держвидав України, 1926. 167 с.

4. Даниленко В. Я. Дизайн України у світовому контексті художньо-проектної культури: монографія. Харків: ХДАДМ; Колорит, 2005. 244 с.

5. Івашко Ю. Специфіка шкіл модерну в Україні та проблема зовнішніх впливів. Українське мистецтвознавство: матеріали, дослідження, рецензії. Київ: ІМФЕ ім. М. Т. Рильського НАН України, 2009. Вип. 9. С. $293-298$.

6. Каталог выставки художника Георгия Ивановича Нарбута. Графика: Из собраний Харьковского художественного музея, Одесского Дома-музея им. Н. К. Рериха, личной коллекции Т. И. Максимюка / сост. Г. Фисан и др; ред. кол. Е. Петренко и др.; Одеса: Астропринт, 2006. 184 с.

7. Король А. Теоретичні аспекти класифікації пластичних мистецтв. Молодь і ринок. 2012. № 1. С. 141-146.

8. Лагутенко О. А. Українська графіка першої третини ХХ століття. Київ: Грані-Т, 2006. 240 с.

9. Ламонова О. Книжкова графіка. Історія українського мистецтва: у 5 т. / голов. ред. Г. Скрипник. Київ, 2007. Т. 5: Мистецтво ХХ століття. С. 132-175; 556-577.

10. Макарова А. Л. Метафора в графическом дизайне как средство художественного выражения в логико-семиотической модели визуального язика. Культура народов Причерноморья. 2012. № 231. С. 116-119.

11. Народний митець: тези доп. та повідомлень до наук. конф., присвяченої 100-річчю $з$ дня народження славетного українського графіка Георгія Нарбута (1886-1920) / уклад. С. Побожій, О. Кузьменко; Сумський художній музей. Суми: Сумська обласна організація товариства любителів книги УРСР, 1986. 27 с.

12. Петрова О. Живопис. Історія українського мистецтва: у 5 т. / Голов. ред. Г. Скрипник. Київ, 2007. Т. 5 : Мистецтво ХХ століття. С. 450-509.

13. Роготченко О. Графіка. Історія українського мистецтва: у 5 т. / Голов. ред. Г. Скрипник. Київ, 2007. Т. 5 : Мистецтво ХХ століття. С. 308-347.

14. Сбитнева Н. Ф. «Коммерческий» стиль в графическом дизайне: особенности и перспективы развития. Вісник Харківської державної академії дизайну і мистецтв. Мистецтвознавство. Архітектура. 2007. № 6. С. 153-163.

15. Ювілей НАОМА: шляхи розвитку українського мистецтвознавства (до 130-річчя від дня народження Г. Нарбута): тези і матеріали доп. Всеукр. наук. конф. молодих науковців, аспірантів і студентів, 22 квіт. 2016 р. / Нац. акад. образотвор. мистецтва і архітектури, Каф. теорії та історії мистецтва. К.: Фенікс, 2017. 139 с.

16. Юрченко I. А. Особливості інтерпретації етнокультурних традицій у сучасних галузях дизайну. Українська культура: минуле, сучасне, шляхи розвитку. 2014. Вип. 20(2). С. 128-132.

\section{REFERENCES}

1. Andreikanich A. I. Plakat: yoho vydy ta zhanry [Poster: its Types and Genres]. Ukrainska kultura: mynule, suchasne, shliakhy rozvytku. 2013. Vyp. 19(1). pp. 121-126. [in Ukrainian]. 
2. Burachek M. Spohady pro H. I. Narbuta [Memoirs about H. I. Narbut]. Bibliolohichni visti. 1927. № 1. Pp. 91-101. [in Ukrainian].

3. Heorhii Narbut: posmertna vyst. tvoriv. Vseukr. ist. muzei im. T. Shevchenka [Heorgii Narbut: Post-Mortem Exhibition of Works]. Kyiv: Derzhvydav Ukrainy, 1926. 167 p. [in Ukrainian].

4. Danylenko V. Ia. Dyzain Ukrainy u svitovomu konteksti khudozhno-proektnoi kultury: monohrafiia [Design of Ukraine in the World Context of Art and Design Culture: Monograph]. Kharkiv: KhDADM; Koloryt, 2005. 244 p. [in Ukrainian].

5. Ivashko Yu. Spetsyfika shkil modernu v Ukraini ta problema zovnishnikh vplyviv. Ukrainske mystetstvoznavstvo: materialy, doslidzhennia, retsenzii. Kyiv: IMFE im. M. T. Rylskoho NAN Ukrainy, 2009. Vyp. 9. Pp. 293-298. [in Ukrainian].

6. Katalog vystavki hudozhnika Georgija Ivanovicha Narbuta. Grafika: Iz sobranij Har'kovskogo hudozhestvennogo muzeja, Odesskogo Doma-Muzeja im. N. K. Reriha, lichnoj kollekcii T. I. Maksimjuka [Catalogue of the Exhibition by the Artist Heorgii Ivanovych Narbut. Graphics: From the Collections of the Kharkov Art Museum, Odessa House-Museum of N. K. Rerykh, Personal Collection of T. I. Maksymiuk] / sost. G. Fisan i dr; red. kol. E. Petrenkoi dr.; Odesa: Astroprint, 2006. 184 p. [in Russian].

7. Korol A. Teoretychni aspekty klasyfikatsii plastychnykh mystetstv [Theoretical Aspects of the Classification of Plastic Arts]. Molod i rynok. 2012. № 1. Pp. 141-146. [in Ukrainian].

8. Lahutenko O. A. Ukrainska hrafika pershoi tretyny XX stolittia [Ukrainian Graphics of the First Third of the 20th century]. Kyiv: Hrani-T, 2006. 240 p. [in Ukrainian].

9. Lamonova O. Knyzhkova hrafika. Istoriia ukrainskoho mystetstva: u 5 t. [Book Graphics. History of Ukrainian Art: in 5 Volumes] / holov. red. H. Skrypnyk. Kyiv, 2007. T. 5: Mystetstvo XX stolittia. pp. 132-175; 556-577. [in Ukrainian].

10. Makarova A. L. Metafora v hrafychesom dyzaine kak sredstvo khudozhestvennoho vyrazhenyia v lohyko-semyotycheskoi modely vyzualnoho yazyka [Metaphor in Graphic Design as a Means of Artistic Expression in the Logical-Semiotic Model of the Visual Language]. Kultura narodov Prychernomoria. 2012. № 231. Pp. 116-119. [in Russian].

11. Narodnyi mytets: tezy dop. ta povidomlen do nauk. konf., prysviachenoi 100-richchiu z dnia narodzhennia slavetnoho ukrainskoho hrafika Heorhiia Narbuta (1886-1920) [People's Artist: Brief Outline Reports of the Scientific and Practical Conference Devoted to the 100th Anniversary of the Birth of the Glorious Ukrainian Graphic Artist Heorhii Narbut (18861920)] / uklad. S. Pobozhii, O. Kuzmenko; Sumskyi khudozhnii muzei. Sumy: Sumska oblasna orhanizatsiia tovarystva liubyteliv knyhy URSR, 1986. 27 p. [in Ukrainian].

12. Petrova O. Zhyvopys. Istoriia ukrainskoho mystetstva: u 5 t. [Painting. History of Ukrainian Art: in 5 volumes. / Ed. By H. Skrypnyk, Vol. 5] / holov. red. H. Skrypnyk. Kyiv, 2007. T. 5: Mystetstvo XX stolittia. pp. 450-509. [in Ukrainian].

13. Rohotchenko O. Hrafika. Istoriia ukrainskoho mystetstva: u 5 t. [Graphics. History of Ukrainian Art: in 5 vol.] / holov. red. H. Skrypnyk. Kyiv, 2007. T. 5: Mystetstvo XX stolittia. Pp. 308-347. [in Ukrainian].

14. Sbitneva N. F. «Kommercheskij» stil' v graficheskom dizajne: osobennosti i perspektivy razvitija ["Commercial" Style in Graphic Design: Features and Prospects of Development]. Visnik Harkivs'koï derzhavnoï akademiï dizajnu i mistectv. Mistectvoznavstvo. Arhitektura. 2007. № 6. Pp. 153-163. [in Russian].

15. Iuvilei NAOMA: shliakhy rozvytku ukrainskoho mystetstvoznavstva (do 130-richchia vid dnia narodzhennia H. Narbuta): tezy i materialy dop. Vseukr. nauk. konf. molodykh naukovtsiv, aspirantiv i studentiv, 22 kvit. 2016 r. [Anniversary of NAOMA: Ways of Development of Ukrainian Art Studies (To the 130th Anniversary of the Birth of H. Narbut): Brief Outline Reports and Materials of All-Ukrainian Scientific and Practical Conference of Young Scientists, Postgraduate Students and Students, April 22, 2016] / Nats. akad. obrazotvor. mystetstva i arkhitektury, Kaf. teorii ta istorii mystetstva. K.: Feniks, 2017. 139 p. [in Ukrainian].

16. Yurchenko I. A. Osoblyvosti interpretatsii etnokulturnykh tradytsii u suchasnykh haluziakh dyzainu [Features of Interpreting Ethnic Cultural Traditions in Modern Design Areas]. Ukrainska kultura: mynule, suchasne, shliakhy rozvytku. 2014. Vyp. 20(2). pp. 128-132. [in Ukrainian]. 